УДК 622.235

DOI: https://doi.org/10.26642/ten-2020-2(86)-179-184

О.О. Фролов, Д.Т.н., проф.

М.I. Бельтек, аспірант

Національний технічний університет Украӥни

«Київський політехнічний інститут імені Ігоря Сікорського»

\title{
Визначення радіуса зони вибухового розпушення тріщинуватого скельного гірського масиву при підриванні свердловинного заряду
}

Представлено результати наукових досліджень щуодо встановлення радіуса зони вибухового розпушення тріщинуватих гірських масивів під час підривання в ньому свердловинного заряду вибухової речовини. Встановлено, щзо параметри зони вибухового розпушення залежать від розмірів зони інтенсивного дроблення та тріщиноутворення, які формуються під дією вибуху у скельному монолітному масиві та залежать від діаметра заряду, щільності заряджання та швидкості детоначї вибухової речовини, меж міцності гірських порід на стиснення $і$ зсув.

Отримано аналітичну залежність з визначення радіуса зони вибухового розпушення 6 трішинуватих масивах, яка пов'язуе основні характеристики гірського масиву та заряду вибухової речовини. Доведено, що радіус зони вибухового розпушення збільшується, порівняно з радіусом зони тріщиноутворення у монолітному масиві, обернено пропориійно коефіцієнту структурного ослаблення, який у свою чергу залежить від середньої відстані між тріщчинами.

Для гірничо-геологічних та технологічних умов залізорудного кар'єру розраховані значення радіуса зони розпушення залежно від відстані між природними тріщинами у гірському масиві під час руйнування його свердловинними зарядами вибухової речовини. Встановлено, щуо при зміні відстані між тріщинами з 0,1 до 2,0 м значення радіуса зони розпушення зменшується з 6,24 до 3,09 м, тобто у 2,01 раза. При изьому найбільша інтенсивність його зменшення припадає на масив II категорії тріщинуватості і чисельне значення зменшується у 1,65 раза при збільшенні відстані між тріщинами з 0,1 до 0,5 м.

Отримані результати дозволяють для будь-яких гірничо-геологічних $і$ технологічних умов розробки родовища проєктувати раціональні параметри буропідривних робіт, в основі яких закладено врахування радіуса зони вибухового розпушення гірського масиву під час підривання в ньому подовжених зарядів.

Ключові слова: вибух; зона вибухового розпушення; інтенсивне дроблення; гірський масив; тріщинуватість; вибухові роботи; радіус зони тріщиноутворення.

Постановка проблеми та її зв'язок з важливими практичними завданнями. Під час дії вибуху циліндричного заряду вибухової речовини (ВР) на монолітний гірський масив у ньому утворюються три зони: зона інтенсивного дроблення (зминання); зона тріщиноутворення (радіальних тріщин); зона пружних деформацій [1]. Як правило, між цими зонами немає чітких меж. Вони поступово переходять одна в одну і радіус зони тріщиноутворення визначає параметри загальної зони дроблення. Процеси формування цих зон та їх параметри залежать як від характеристик ВР та зарядної порожнини, так і від властивостей гірського масиву, який підлягає руйнуванню. Визначення розмірів зон інтенсивного дроблення та радіальних тріщин має дуже важливе значення під час проведення вибухових робіт на гірничих підприємствах для встановлення ефективності руйнування гірського масиву [2, 3].

В той же час загальновідомо, що переважна більшість гірських масивів, які підлягають промисловому руйнуванню, є тріщинуватими і при дії на них вибухового навантаження більша частина породи розвалюється за існуючими в масиві тріщинами. При цьому лише певна частина масиву, прилеглого до заряду, піддається дробленню на шматки менше природної окремості. Обсяг зони вибухового розпушення та обсяг інтенсивного дроблення залежать, як і у випадку дроблення монолітного середовища, від характеристики застосовуваної ВР та від міцності й тріщинуватості гірських порід [4]. Тому проблемі вибухового руйнування тріщинуватого масиву завжди приділяється значна увага, а встановлення розмірів зазначених вище зон руйнування в різноманітних гірничогеологічних і гірничотехнічних умовах становить наукотехнічну задачу, розв'язання якої дає можливість ефективно керувати дією вибуху в гірському масиві.

Аналіз останніх досліджень і публікацій. Серед науковців не існує єдиного погляду на питання формування та параметрів зон руйнування скельного гірського масиву. Зокрема, це стосується розмірів зони інтенсивного дроблення, розташованої за межею «вибухова речовина - гірський масив». Ця зона існує як у монолітному, так і в тріщинуватому гірських масивах і вважається одним з основних критеріїв оцінки ефективності руйнування скельного середовища. Покровський Г.І. стверджував, що після детонації заряду ВР скельна гірська порода в приконтактній зоні вибуху зазнає пластичної деформації, а 
з віддаленням від заряду ці деформації стають пружно-пластичними. В той же час В.Н. Родіонов вважав, що на контакті «заряд ВР - гірський масив» відбувається крихке руйнування скельних порід внаслідок пружної дії вибуху. Не зважаючи на різні точки зору на критерії вибухового руйнування скельних порід безпосередньо біля заряду, усіма дослідниками беззаперечно виокремлюється зона інтенсивного дроблення [5, 6], в якій гірська порода змінює свою структуру, внаслідок інтенсивного переподрібнення. Розміри зони інтенсивного дроблення вчені встановлюють також різні. Так згідно 3 [5] зона зминання становить в середньому $(0,3 \ldots 0,5)$ радіуса заряду, але не більше одного радіуса, а в [2, 7] ця зона може мати розміри від одного до декількох радіусів заряду (рис. 1).

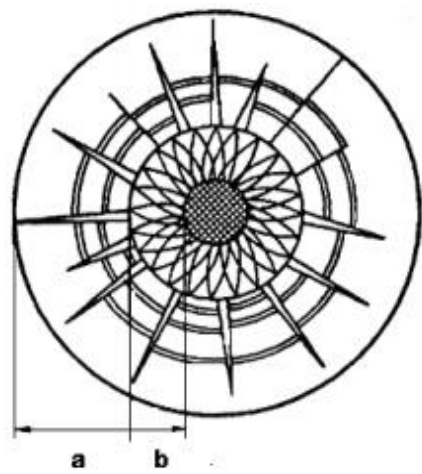

Рис. 1. Схема руйнування скельного монолітного масиву гірських порід: $a$ - зона тріщиноутворення; $b$-зона інтенсивного дроблення [5]

Під час підривання подовжених циліндричних зарядів у скельному середовищі основний об'єм руйнувань припадає на зону тріщиноутворення [8] і в монолітному гірському масиві вона визначає параметри загальної зони дроблення. Утворення зони радіальних тріщин у монолітному масиві досліджувалося багатьма науковцями [9], за результатами цих досліджень запропоновано декілька формул для розрахунку радіуса зони дроблення [10].

Щодо характеристик зони вибухового розпушення порушених тріщинами гірських масивів під час дії на них вибухового навантаження, то тут також немає єдиної наукової думки [11]. Достатньо вивченим $\epsilon$ вибухове руйнування монолітного середовища із зазначенням розмірів зон інтенсивного дроблення i тріщиноутворення під час дії на нього зосередженого заряду ВР. Менш вивченим i, відповідно, достовірним $є$ питання руйнування суцільного масиву подовженими циліндричними зарядами ВР. Руйнування ж тріщинуватих гірських порід $є$ набагато складнішим науковим завданням. Незважаючи на існуючі наукові дослідження у цій сфері й досягнуті певні результати, на сьогодні неможливо достовірно передбачити результат дії вибуху у тріщинуватому масиві, оскільки він $\epsilon$, певною мірою, ймовірнісним через неможливість точного встановлення параметрів тріщинуватості.

Мета дослідження. На підставі наведеного вище аналізу літературних джерел сформована мета досліджень, яка полягає у визначенні радіуса зони вибухового розпушення тріщинуватих гірських масивів як показника ефективності вибухової відбійки та встановлення впливу насиченості масиву тріщинами на розміри цієї зони. Актуальність вирішення означеного питання є безумовним, оскільки тріщинуватістю володіє переважна більшість скельних гірських масивів розроблюваних родовищ.

Викладення основного матеріалу. Як вже зазначалося, сьогодні велика увага приділяється проблемі вибухового руйнування тріщинуватого масиву, оскільки в реальних умовах виробництва гірський масив фактично таким і є [12]. Для практичного застосування дослідниками пропонується декілька способів розрахунку параметрів буропідривних робіт у таких умовах розробки родовища. Однак вони не набули загального поширення, оскільки жоден з них не враховує повною мірою тих чинників, які впливають на ефективність руйнування тріщинуватих масивів гірських порід вибухом подовженого заряду. Зокрема, одні способи не враховують величину і дію вибухового імпульсу на навколишнє середовище, інші занадто спрощують вплив тріщинуватості масиву. Проте найбільш повно величина вибухового імпульсу і розмір зони впливу вибуху відображено у чисельному значенні радіуса тріщиноутворення за умови відбійки монолітного масиву.

Енергія вибуху у монолітному середовищі передається хвилею напружень i поширюється продуктами (газами) вибуху. 3 численних експериментальних і теоретичних досліджень відомо, що розташований на певній відстані від осі циліндричного заряду об'єм породи починає руйнуватися не в момент поширення в ньому хвилі напружень, а після нього. Досліди в лабораторних умовах i спостереження на виробництві показують, що руйнування в такому об'ємі починає відбуватися через деякий час після проходження хвилі напружень. Про це також свідчить те, що швидкість поширення 
тріщин руйнування в монолітному середовищі є меншою, ніж швидкість хвилі напружень. Залежно від фізико-механічних властивостей скельних гірських порід швидкість поширення радіальних тріщин менша за швидкість хвилі напружень на 30-90\% [13]. Таким чином, хоча руйнування гірського масиву і пов'язане з поширенням хвиль напружень, однак зону руйнування недоцільно визначати за напруженим станом, який формується в масиві під їхнім впливом. Як зазначається багатьма науковцями, хвилі напружень передруйнують середовище, тобто формують умови для його руйнування газами вибуху [14], а саме дроблення (руйнування) монолітного гірського масиву відбувається за рахунок тиску продуктів детонації ВР, який формується всередині зарядної порожнини.

Таким чином, з огляду на викладене вище, для визначення радіуса зони тріщиноутворення у монолітному гірському масиві під час дії на нього вибухового навантаження запропоновано використовувати розрахункову залежність [13]:

$$
R_{\text {тр }}=1,4 R_{\text {п }} \sqrt{\frac{P_{\mathrm{BP}} r_{\mathrm{cB}}}{R_{\mathrm{n}} \tau}}, \mathrm{M},
$$

де $R_{\text {п }}$ - радіус зони інтенсивного дроблення гірського масиву, яка утворюється під час підривання в

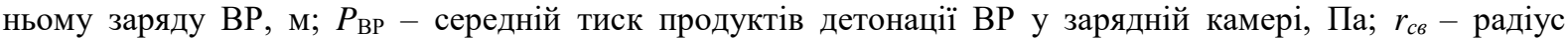
циліндричного заряду (свердловини або шпуру), м; $\tau$ - межа міцності руйнування гірської породи на зсув, Па.

Значення радіуса зони тріщиноутворення в гірському масиві можна використовувати для наближеної оцінки розмірів воронки руйнування, що утворюється під час вибуху подовженого заряду поблизу вільної поверхні.

Слід зазначити, що формула (1) як визначальну складову містить радіус зони інтенсивного дроблення. У цій зоні, після вибуху заряду, відбувається інтенсивне дрібнодисперсне дроблення породи, яка переходить у розрихлений стан і під час дії вибуху поводить себе як середовище зі слабким зчепленням. Радіус зони інтенсивного дроблення у монолітному масиві, згідно з [6], визначається:

$$
R_{\mathrm{n}}=d \sqrt{\frac{P_{\mathrm{BP}}}{\sigma_{\mathrm{c}}}}, \mathrm{м},
$$

де $d$ - діаметр циліндричного заряду ВР, м; $\sigma_{c}$ - межа міцності гірських порід на стиснення, Па.

Середній тиск продуктів детонації ВР у заряді, Па, можна розрахувати за формулою [15]:

$$
P_{\mathrm{BP}}=\frac{1}{8} \rho_{\mathrm{BP}} D^{2},
$$

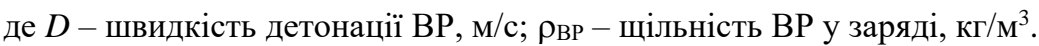

Згідно $з$ дослідженнями, проведеними у роботі [16], радіус зони вибухового розпушення у порушених тріщинами гірському масиві, під час підривання в ньому подовженого заряду, рекомендовано визначати як:

$$
R_{\mathrm{p}}=1,4 R_{\mathrm{\Pi}} \sqrt{\frac{P_{\mathrm{BP}} r_{\mathrm{cB}}}{R_{\mathrm{n}} \tau K_{\mathrm{c}}}},
$$

де $K_{\mathrm{c}}$ - коефіцієнт структурного ослаблення тріщинуватого масиву, що підлягає руйнуванню.

Аналіз формули (4) свідчить, що вона відрізняється від формули 3 визначення радіуса зони тріщиноутворення у монолітному масиві лише наявністю коефіцієнта структурного ослаблення тріщинуватого масиву, який, згідно з [13], найбільш достовірно апроксимується виразом:

$$
K_{\mathrm{c}}=\frac{1}{0,97+0,13 \frac{R_{\text {тр }}}{l_{\text {т }}}},
$$

де $l_{\text {т }}$ - середня відстань між тріщинами.

Таким чином встановлено, що в тріщинуватих масивах гранично можливий радіус зони розпушення збільшується обернено пропорційно коефіцієнту структурного ослаблення, який функціонально визначається зі співвідношення гранично можливого радіуса зони тріщиноутворення у монолітному масиві до середньої відстані між тріщинами.

3 урахуванням (1) та (5) формула (4) набуде вигляду:

$$
R_{\mathrm{p}}=1,4 R_{\mathrm{\Pi}} \sqrt{\frac{P_{\mathrm{BP}} r_{\mathrm{cB}}\left(0,97+0,182 \sqrt{\frac{R_{\mathrm{\Pi}} P_{\mathrm{BP}} r_{\mathrm{cB}}}{l_{\mathrm{T}}^{2} \tau}}\right)}{R_{\mathrm{\Pi}} \tau}} .
$$

Аналіз формули (6) свідчить, що вона враховує як основні властивості гірського масиву (міцнісні характеристики та тріщинуватість), так і параметри буропідривних робіт, а саме радіус заряду та властивості вибухової речовини. 
Для тріщинуватого гірського масиву, складеного 3 магнетитових кварцитів, який руйнується вибухом свердловинного заряду ВР Анемікс 70, при різних відстанях між основними тріщинами $l_{\mathrm{T}}$, розраховані значення радіуса зони вибухового розпушення $R_{\mathrm{p}}$ за наступних умов: межа міцності гірських порід на стиснення $\sigma_{\mathrm{c}}=2,1 \cdot 10^{8}$ Па; межа міцності руйнування масиву магнетитових кварцитів на зсув $\tau=1,25 \cdot 10^{8}$ Па; радіус свердловинного заряду $r_{\text {св }}=0,125$ м; щільність Анеміксу 70 у свердловинному

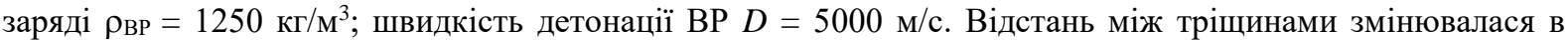
межах від 0,1 до 2 м з інтервалом 0,1 м.

У таблиці 1 наведено результати розрахунку радіуса зони вибухового розпушення залежно від відстані між тріщинами у гірському масиві для зазначених вище умов, а на рисунку 2 побудовано відповідну графічну залежність.

Таблиия 1

Значення радіуса зони вибухового розпушення під час вибуху свердловинного заряду залежно від відстані між тріщинами в гірському масиві магнетитових кварциитів

\begin{tabular}{|c|c|c|c|c|c|c|c|c|c|c|}
\hline$l_{\mathrm{T}} \mathrm{M}$ & 0,1 & 0,2 & 0,3 & 0,4 & 0,5 & 0,6 & 0,7 & 0,8 & 0,9 & 1,0 \\
\hline$R_{\mathrm{p}}, \mathrm{M}$ & 6,239 & 4,845 & 4,280 & 3,968 & 3,768 & 3,629 & 3,526 & 3,447 & 3,384 & 3,333 \\
\hline$l_{\mathrm{T}}, \mathrm{M}$ & 1,1 & 1,2 & 1,3 & 1,4 & 1,5 & 1,6 & 1,7 & 1,8 & 1,9 & 2,0 \\
\hline$R_{\mathrm{p}}, \mathrm{M}$ & 3,291 & 3,255 & 3,224 & 3,198 & 3,175 & 3,154 & 3,136 & 3,120 & 3,106 & 3,093 \\
\hline
\end{tabular}

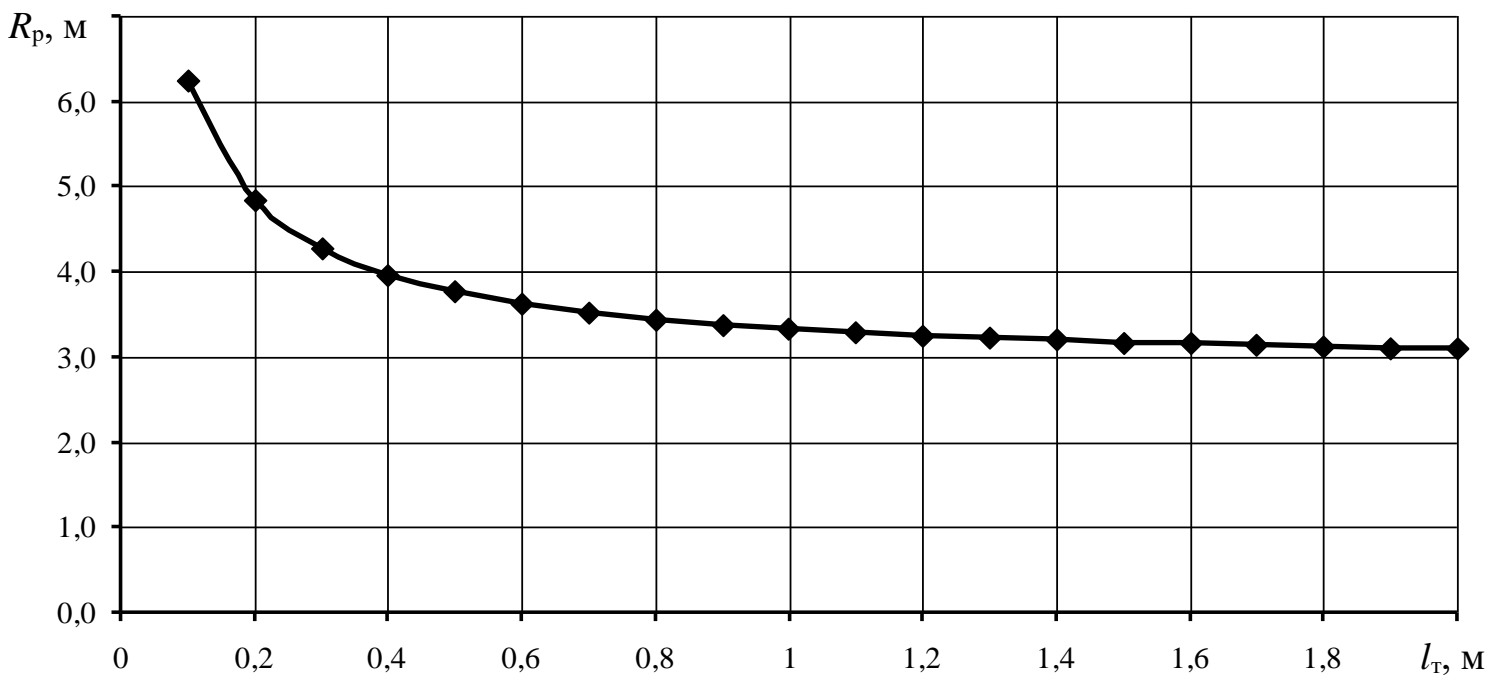

Рис. 2. Зміна радіуса зони вибухового розпушення тріщинуватих магнетитових кварцฺитів $R_{\mathrm{p}}$ залежно від відстані між тріщинами в гірському масиві $l_{\mathrm{T}}$

Аналіз даних, наведених в таблиці 1 та на рисунку 2, показує, що за таких гірничо-геологічних умов радіус зони вибухового розпушення зменшується зі збільшенням відстані між тріщинами. Для надзвичайно тріщинуватого (I категорія тріщинуватості) гірського масиву з відстанню між природними тріщинами до 0,1 м чисельне середнє значення радіуса зони вибухового розпушення становить 6,24 м. Для сильно тріщинуватих скельних масивів (II категорія тріщинуватості) з максимальною відстанню між тріщинами 0,5 м значення радіуса зони вибухового розпушення значно зменшується і становить 3,77 м. Для III категорії тріщинуватості гірських порід (середньотріщинуватий масив) 3 відстанню між тріщинами до 1 м вказаний параметр зменшується до значення 3,33 м, тобто в порівнянні $з$ попередньою категорією зменшення становить 0,5 м, або близько 15 \%. Для малотріщинуватих масивів (IV категорія) радіус зони вибухового розпушення становить 3,18 м для граничної відстані між тріщинами 1,5 м і для практично монолітних скельних порід V категорії тріщинуватості, де відстань між тріщинами становить більше 1,5 м, розміри зони розпушення майже не зменшуються (при зміні відстані між тріщинами 31,5 до 2,0 м радіус зменшується з 3,18 до 3,09 м). В цілому ж на досліджуваному інтервалі зміни відстані між тріщинами з 0,1 до 2,0 м радіус зони розпушення зменшується 3 6,24 до 3,09 м, тобто у 2,01 раза. Найбільша інтенсивність зменшення радіуса припадає на II категорію тріщинуватості гірського масиву, де його значення зменшується у 1,65 раза при збільшенні відстані між тріщинами до 0,5 м.

Висновки та перспективи подальших досліджень. За результатами проведених наукових досліджень встановлено, що розміри зон інтенсивного дроблення та тріщиноутворення, які з'являються 
під час вибуху свердловинного заряду у монолітному гірському масиві, залежать від діаметра заряду ВР, щільності заряджання та швидкості детонації ВР, меж міцності гірських порід на стиснення і зсув.

Радіус зони вибухового розпушення в тріщинуватих масивах збільшується, порівняно 3 радіусом зони тріщиноутворення у монолітному масиві, обернено пропорційно до коефіцієнта структурного ослаблення, який в свою чергу залежить від середньої відстані між тріщинами.

Отримано формулу для визначення радіуса зони вибухового розпушення в тріщинуватих масивах, яка пов'язує основні характеристики гірського масиву та заряду вибухової речовини.

Для певних гірничо-геологічних та технологічних умов залізорудного кар'єру виконано розрахунки радіусів зон вибухового розпушення під час підривання свердловинних зарядів у тріщинуватому гірському масиві за різних відстаней між природними тріщинами. Встановлено, що при зміні відстані між тріщинами з 0,1 до 2,0 м радіус зони розпушення зменшується з 6,24 до 3,09 м, тобто у 2,01 раза. Інтенсивність зменшення зазначеного параметра $є$ найбільшою для масиву II категорії тріщинуватості і становить 65 \% при збільшенні відстані між тріщинами з 0,1 до 0,5 м.

Отримані дані дозволяють продовжити наукові дослідження у цьому напрямі. Зокрема, перспективними $€$ дослідження 3 визначення параметрів зони вибухового розпушення під час застосування різних типів ВР у різноманітних гірничо-геологічних умовах.

\section{Список використаної літератури:}

1. Шер Е.Н. Исследование влияния конструкции скважинного заряда на размер зоны разрушения и время ее развития в горных породах при взрыве / Е.Н. Шер, Н.И. Александрова // ФТПРПИ. - 2007. - № 4. - С. $76-85$.

2. Головин К.A. Прогнозирование расположения зон разрушения массива в ходе проведения взрывных работ $/$ К.А. Головин, Р.А. Ковалев, А.Б. Копылов // Известия ТулГУ. Науки о Земле. - 2017. - № 4. - С. 293-302.

3. К вопросу о механизме разрушения прочных скальных пород подземным взрывом / B.B. Адушкин, Г.Г. Кочарян, И.В. Бригадин и др. // ГИАБ. - 2015. - № 7. - С. 344-349.

4. Фролов О.О. Встановлення закономірностей руйнування природно порушених скельних масивів вибухом / О.О. Фролов, М.I. Бельтек // Вісник ЖДТУ. Технічні науки. - 2019. - № 1 (83). - С. 283-288.

5. Кутузов Б.Н. Методы ведения взрывных работ. Часть 1. Разрушение горных пород взрывом / Б.Н. Кутузов ; МГГУ. - М. : Горная книга, 2009. - 471 с.

6. Андриевский А.П. Гипотезы дробления массива взрывом колонкового заряда / А.П. Андриевский, А.E. Зуев // Международный научно-исследовательский журнал. - 2015. - № 10 (41). - Ч. 4. - С. 86-90.

7. Боровиков В.А. Моделирование действия взрыва при разрушении горных пород / В.А. Боровиков, И.Ф. Ванягин. - М. : Недра, 1990. - 231 с.

8. Шер Е.Н. Форма и размеры радиальных трещин, образующихся при взрыве двух сближенных скважинных зарядов / Е.Н. Шер // Фундаментальные и прикладные вопросы горных наук. - 2016. - № 3. - С. 250-255.

9. Фролов О.О. Лабораторні дослідження впливу хвиль напружень під час вибуху на параметри руйнування моделі / О.О. Фролов, В.В. Котенко // Вісник ЖДТУ. Технічні науки. - 2014. - № 3 (70). - С. 124-128.

10. Фролов О.О. Керування енергетичними потоками при вибуховому руйнуванні різноміцнісних масивів гірських порід на кар'єрах : дис. ... д-ра техн. наук : 05.15.03 / О.О. Фролов. - К., 2014. - 369 с.

11. Кутузов Б.Н. Новая теория и новая технология разрушения горных пород удлиненными зарядами взрывчатых веществ / Б.Н. Кутузов, А.П. Андриевский. - Новосибирск : Наука, 2002, - 96 с.

12. Казаков Н.Н. Разрушение и дробление горных пород в карьерах / Н.Н. Казаков // Взрывное дело. - 2018. № 119/76. - С. 5-19.

13. Андриевский А.П. Физико-техническое обоснование параметров разрушения горного массива взрывом удлиненных зарядов : дисс. ... д-ра техн. наук : 25.00.20 / А.П. Андриевский. - Красноярск, 2009. - 349 с.

14. Фролов О.О. Керування енергетичними потоками при вибуховому руйнуванні гірських порід на кар'єрах : монографія / О.О. Фролов, А.І. Крючков, Т.В. Косенко. - Київ : Вид-во «Політехніка» КПІ імені Ігоря Сікорського, 2019. $-196 \mathrm{c}$.

15. Кравеиъь В.Г. Фізичні процеси прикладної геодинаміки вибуху : монографія / В.Г. Кравещъь, В.В. Коробійчук, B.В. Бойко. - Житомир : ЖДТУ, 2015. - 408 с.

16. Влияние физико-механических свойств и трещиноватости массива на параметры образующейся взрывной воронки при отбойке на обнаженную плоскость / А.П. Андриевский, Б.Н. Кутузов, Б.Д. Половов и др. // ФТПРПИ. - 1997. - № 4. - С. 59-61.

\section{References:}

1. Sher, E.N. and Aleksandrova, N.I. (2007), «Issledovanie vliyaniya konstruktsii skvazhinnogo zaryada na razmer zony razrusheniya i vremya ee razvitiya v gornykh porodakh pri vzryve», FTPRPI, No. 4, pp. 76-85.

2. Golovin, K.A., Kovalev, R.A. and Kopylov, A.B. (2017), «Prognozirovanie raspolozheniya zon razrusheniya massiva v khode provedeniya vzryvnykh rabot», Izvestiya TulGU. Nauki o Zemle, No. 4, pp. 293-302.

3. Adushkin, V.V., Kocharyan, G.G., Brigadin, I.V. et al. (2015), «K voprosu o mekhanizme razrusheniya prochnykh skal'nykh porod podzemnym vzryvom», GIAB, No. 7, pp. 344-349.

4. Frolov, O.O. and Bel'tek, M.I. (2019), «Vstanovlennja zakonomirnostej rujnuvannja pryrodno porushenyh skel'nyh masyviv vybuhom», Visnyk ZhDTU. Tehnichni nauky, No. 1 (83), pp. 283-288. 
5. Kutuzov, B.N. (2009), Metody vedeniya vzryvnykh rabot. Chast' 1. Razrushenie gornykh porod vzryvom, MGGU, Gornaya kniga, Moscow, $471 \mathrm{p}$.

6. Andrievskii, A.P. and Zuev, A.E. (2015), «Gipotezy drobleniya massiva vzryvom kolonkovogo zaryada», Mezhdunarodnyi nauchno-issledovatel'skii zhurnal, No. 10 (41), Vol. 4, pp. 86-90.

7. Borovikov, V.A. and Vanyagin, I.F. (1990), Modelirovanie deistviya vzryva pri razrushenii gornykh porod, Nedra, Moscow, $231 \mathrm{p}$.

8. Sher, E.N. (2016), «Forma i razmery radial'nykh treshchin, obrazuyushchikhsya pri vzryve dvukh sblizhennykh skvazhinnykh zaryadov», Fundamental'nye i prikladnye voprosy gornykh nauk, No. 3, pp. 250-255.

9. Frolov, O.O. and Kotenko, V.V. (2014), «Laboratorni doslidzhennja vplyvu hvyl' napruzhen' pid chas vybuhu na parametry rujnuvannja modeli», Visnyk ZhDTU. Tehnichni nauky, No. 3 (70), pp. 124-128.

10. Frolov, O.O. (2014), «Keruvannja energetychnymy potokamy pry vybuhovomu rujnuvanni riznomicnisnyh masyviv girs'kyh porid na kar'jerah», D.Sc. Thesis of dissertation, Kyiv, 369 p.

11. Kutuzov, B.N. and Andrievskii, A.P. (2002), Novaya teoriya i novaya tekhnologiya razrusheniya gornykh porod udlinennymi zaryadami vzryvchatykh veshchestv, Nauka, Novosibirsk, $96 \mathrm{p}$.

12. Kazakov, N.N. (2018), «Razrushenie i droblenie gornykh porod v kar'erakh», Vzryvnoe delo, No. 119/76, pp. 5-19.

13. Andrievskii, A.P. (2009), «Fiziko-tekhnicheskoe obosnovanie parametrov razrusheniya gornogo massiva vzryvom udlinennykh zaryadov», D.Sc. Thesis of dissertation, Krasnoyarsk, 349 p.

14. Frolov, O.O., Krjuchkov, A.I. and Kosenko, T.V. (2019), Keruvannja energetychnymy potokamy pry vybuhovomu rujnuvanni girs'kyh porid na kar'jerah, monografija, Vyd-vo «Politehnika» KPI imeni Igorja Sikors'kogo, Kyi'v, $196 \mathrm{p}$.

15. Kravec', V.G., Korobijchuk, V.V. and Bojko, V.V. (2015), Fizychni procesy prykladnoi' geodynamiky vybuhu, monografija, ZhDTU, Zhytomyr, 408 p.

16. Andrievskii, A.P., Kutuzov, B.N., Polovov, B.D. et al. (1997), «Vliyanie fiziko-mekhanicheskikh svoistv i treshchinovatosti massiva na parametry obrazuyushcheisya vzryvnoi voronki pri otboike na obnazhennuyu ploskost'», FTPRPI, No. 4, pp. 59-61.

Фролов Олександр Олександрович - доктор технічних наук, професор кафедри геобудівництва та гірничих технологій Національного технічного університету України «Київський політехнічний інститут імені Ігоря Сікорського».

Наукові інтереси:

- буропідривні роботи на кар’єрах;

- розробка родовищ корисних копалин.

https://orcid.org/0000-0001-8053-2653.

E-mail: frolov@geobud.kiev.ua.

Бельтек Микита Ігорович - студент Національного технічного університету України «Київський політехнічний інститут імені Ігоря Сікорського».

Наукові інтереси:

- розробка родовищ корисних копалин.

https://orcid.org/0000-0002-8048-0635.

E-mail: nikitabeltek@gmail.com. 